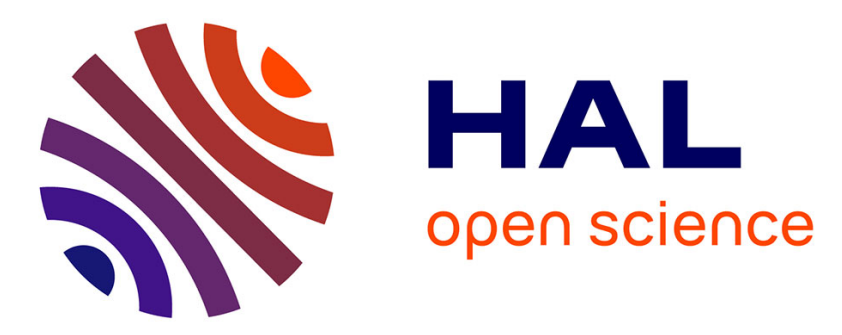

\title{
A socio-scientific analysis of the environmental and health benefits as well as potential risks of cassava production and consumption
}

Stéphane Mombo, Camille Dumat, Muhammad Shahid, Eva Schreck

\section{To cite this version:}

Stéphane Mombo, Camille Dumat, Muhammad Shahid, Eva Schreck. A socio-scientific analysis of the environmental and health benefits as well as potential risks of cassava production and consumption. Environmental Science and Pollution Research, 2016, pp.1-15. 10.1007/s11356-016-8190-z . hal01438416

\author{
HAL Id: hal-01438416 \\ https://hal.science/hal-01438416
}

Submitted on 17 Jan 2017

HAL is a multi-disciplinary open access archive for the deposit and dissemination of scientific research documents, whether they are published or not. The documents may come from teaching and research institutions in France or abroad, or from public or private research centers.
L'archive ouverte pluridisciplinaire $\mathbf{H A L}$, est destinée au dépôt et à la diffusion de documents scientifiques de niveau recherche, publiés ou non, émanant des établissements d'enseignement et de recherche français ou étrangers, des laboratoires publics ou privés. 


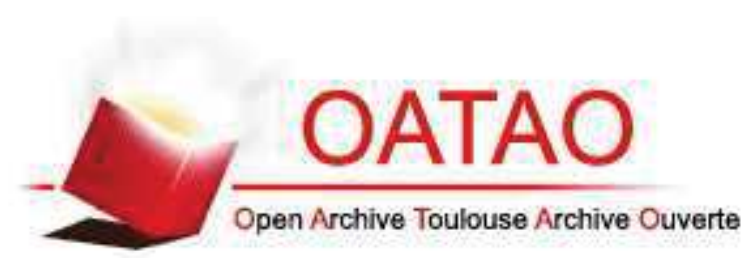

\section{Open Archive TOULOUSE Archive Ouverte (OATAO)}

OATAO is an open access repository that collects the work of Toulouse researchers and makes it freely available over the web where possible.

This is an author-deposited version published in : http://oatao.univ-toulouse.fr/ Eprints ID : 17421

To link to this article : DOI : 10.1007/s11356-016-8190-z

URL : http://dx.doi.org/10.1007/s11356-016-8190-z

To cite this version : Mombo, Stéphane and Dumat, Camille and Shahid, Muhammad and Schreck, Eva A socio-scientific analysis of the environmental and health benefits as well as potential risks of cassava production and consumption. (2016) Environmental Science and Pollution Research. pp. 1-15. ISSN 0944-1344

Any correspondence concerning this service should be sent to the repository administrator: staff-oatao@,listes-diff.inp-toulouse.fr 


\title{
A socio-scientific analysis of the environmental and health benefits as well as potential risks of cassava production and consumption
}

\author{
S. Mombo ${ }^{1,2} \cdot$ C. Dumat ${ }^{1,3} \cdot$ M. Shahid ${ }^{4}$ - E. Schreck ${ }^{5}$
}

\begin{abstract}
Due to its high adaptability, cassava (Manihot esculenta Crantz) is one of the world's most cultivated and consumed plants after maize and rice. However, there are relatively few scientific studies on this important crop. The objective of this review was therefore to summarize and discuss the available information on cassava cropping in order to promote sustainable practices in terms of production and consumption. Cassava cultivation has been expanding recently at the global scale and is widely consumed in most regions of South America, Africa, and Asia. However, it is also characterized by the presence in its roots of potentially toxic hydrocyanic acid. Furthermore, cassava can also absorb pollutants as it is currently cultivated near roads or factories and generally without consideration for potential sources of soil, water, or atmospheric pollution. Careful washing, peeling, and adequate preparation before eating are therefore crucial steps
\end{abstract}

Responsible editor: Hailong Wang

C. Dumat

camille.dumat@ensat.fr

1 Université de Toulouse; INP, ENSAT, Avenue de l'Agrobiopole, 31326 Castanet-Tolosan Cédex, France

2 Université de Toulouse; INP, UPS; EcoLab; ENSAT, Avenue de l'Agrobiopole, 31326 Castanet-Tolosan, France

3 UMR 5044-Centre d'Etude et de Recherche Travail Organisation Pouvoir (CERTOP), Université Toulouse Jean Jaurès, Maison de la Recherche, 5 Allée Antonio Machado, 31058 Toulouse Cedex 9, France

4 Department of Environmental Sciences, COMSATS Institute of Information Technology, Vehari 61100, Pakistan

5 Géosciences Environnement Toulouse (GET), Observatoire Midi Pyrénées, Université de Toulouse, CNRS, IRD, 14 Avenue E. Belin, 31400 Toulouse, France for reducing human exposure to both environmental pollutants and natural hydrocyanic acid. At present, there is not enough precise data available on this staple food crop. To improve our knowledge on the nutritive benefits versus health risks associated with cassava consumption, further research is necessary to compare cassava cultivars and precisely study the influence of preparation methods.

Keywords Cassava crops · Sustainable food · Pollution · Human health $\cdot$ Metal(loid) transfer

\section{Introduction}

Cassava (Manihot esculenta Crantz), a member of the Euphorbiaceae plant family native to South America (Blagbrough et al. 2010), is widely consumed in most African countries for the high starch content in roots (Srinivas 2007; Addo 2010; Zhu et al. 2015). It is also found in Asia and Australia (Burns et al. 2012). Cassava is highly drought resistant and adapts to different environmental conditions even in poor soils and therefore does not require substantial maintenance for optimal growth (Yaninek and Schulthess 1993; Montagnac et al. 2009; Voko and Zeze 2013). As well as being a staple food, cassava is also used in various industrial applications including biofuels, textiles, paper, adhesives, sweeteners, glues, plywood, and many others (Srinivas 2007; Yu and Tao 2009; Li et al. 2015). Its cultivation is increasing worldwide mainly for human consumption: cassava production increased from 230 million $\mathrm{t}$ in 2010 (Zhu et al. 2015) to 277 million $t$ in 2013 (Latif and Müller 2015), and it is now one of the most cultivated plants in the world (after wheat, rice, and maize).

Like other plants, cassava can be exposed to different organic and inorganic pollutants through the soil, atmosphere, or 
water. Persistent trace metal elements (TME) are frequently observed in anthropogenic areas with concentrations above the natural background levels (González et al. 2015; Mombo et al. 2015). The fate of these TME in terms of mobility, bioavailability, phyto-uptake, and compartmentation in different parts of the plant depends on both their chemical form (chemical speciation) and compartmentalization (Shahid et al. 2011; Xiong et al. 2014b; Mombo et al. 2016). Furthermore, in African countries (south of the Sahara), farmers still widely use pesticides and herbicides (Ntow et al. 2006) with little consideration for the environment and health concerns developed by REACH regulation (EC 1907/2006) and food regulations in Europe (Onyedika and Nwosu 2008).

Despite its expansion throughout the world for its crucial role as food, scientific studies on cassava, "the orphaned plant," are scarce. Knowledge regarding the nutritive and health benefits of cassava associated with agronomical practices, environmental pressures, and plant cultivars is therefore necessary to develop sustainable cassava crops. Cassava plant characteristics, such as the size and shape of the webbed cassava leaves, soil-plant and atmosphere-plant transfer of nutrients and pollutants, and its natural toxicity, can vary considerably according to the plant cultivar (Xiong et al. 2014a). Increasing the awareness of farmers and citizens, at the global scale, on the factors that affect the quality of consumed crops, and more precisely cassava, is therefore a crucial health and environment issue (Lichtfouse et al. 2009; Huang et al. 2015; Mombo et al. 2015). Food intake is actually one of the primary routes of human exposure to pollutants (Xiong et al. 2014a; Mombo et al. 2015), and agriculture is an important vector for sustainable development (Ntow et al. 2006).

The objective of this review on cassava is to provide information on the quality of the crop and its advantages and uses throughout the world. We highlight the opportunities and gaps in knowledge concerning cassava cultivation and suggest factors necessary to promote its sustainable development. This review highlights (i) the overall characteristics of cassava cultivars, (ii) its interests for human nutrition, and (iii) its potential health risks due to its chemical composition.

\section{Global characteristics of cassava and its interest for human nutrition}

\section{Characteristics, origins, and production areas in the world}

Cassava is a perennial woody shrub of the Euphorbiaceae family with enlarged tuberous roots (Addo 2010). This annual plant is propagated from woody cuttings, and its growing cycle varies from 6 to 24 months or more depending on weather conditions, altitude, and soil characteristics (Bellotti and Arias 2001). It varies in size from 1 to $2 \mathrm{~m}$ high (Fig. 1) with opposed and large webbed leaves containing three to seven lobes hung on a spotty stem (Fig. 1). Cassava roots vary in number, grow in an oblique direction in the soil, and are 40 to $2 \mathrm{~m}$ in length (Figs. 1 and 2). According to Dórea (2004), more than 5000 varieties of cassava are registered in the world. This is why, differences in cassava quality in terms of nutrient and pollutant contents can certainly occur depending on the cultivar considered. Thus, the name of the studied cultivar should always be included in scientific publications.

Cassava is native to South America, and according to Soccol (1996), it already existed for over 2700 years before Jesus Christ. It was domesticated by the people living along the borders of the Amazon, where it was widely cultivated for over 3000 years (Olsen and Schaal 1999). The Aruak people whose name in their native language means "people who eat the tubers" cultivated cassava many centuries before the arrival of Christopher Columbus (Schmidt 1951). The main reason for which they migrated was to search for the best soils to cassava culture (Nassar 1978).
Fig. 1 Different cassava products (gari, cassava roots, and chikuang)

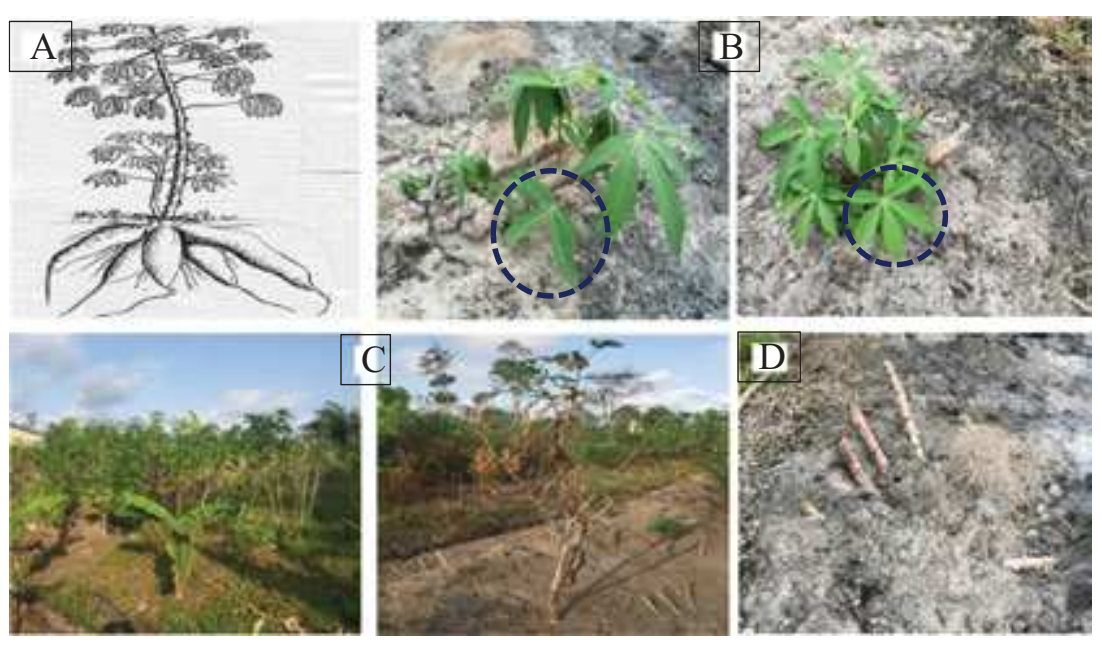


There are 98 wild species of cassava with several geographical origins in the vast region of South America (Sauer 1952) including 38 found in Brazil (Nassar 1978). Cassava was introduced to Africa in the sixteenth century and from Africa to Asia in the seventeenth or eighteenth century (Pandey et al. 2000). Currently, it is cultivated in tropical and subtropical countries of America, Africa, and Asia. In Africa, it is now cultivated across an extensive area, referred to as the "cassava belt" (Bellotti and Arias 2001). More than 105 countries in the world are presently cultivating and producing cassava (Fig. 3). Depending on the country and language, it has many different names: cassava (in Englishspeaking countries in Africa), Timba (Gabon), Bankye (Ghana), Mhogo/Mihogo (Tanzania), Agbeli (Togo), Mandioka (Gambia), Tapioca (Malaysia, Indonesia, India, Pacific countries) (Pandey et al. 2000), Manihot or Mandioca (Latin America), and Mafilinapaka (Malagasy Republic).

Particularly in Africa and South America, the area allocated to cassava culture is increasing rapidly, and over the last 30 years, the area for cassava crops has doubled and is expected to increase further (Burns et al. 2010). Cassava was cultivated over an area of more than 19 million ha in 2010 (Montagnac et al. 2009; Zhu et al. 2015). Approximately $57 \%$ of cassava roots are used for human consumption and $32 \%$ for animal feed and industrial purposes, and $11 \%$ is waste

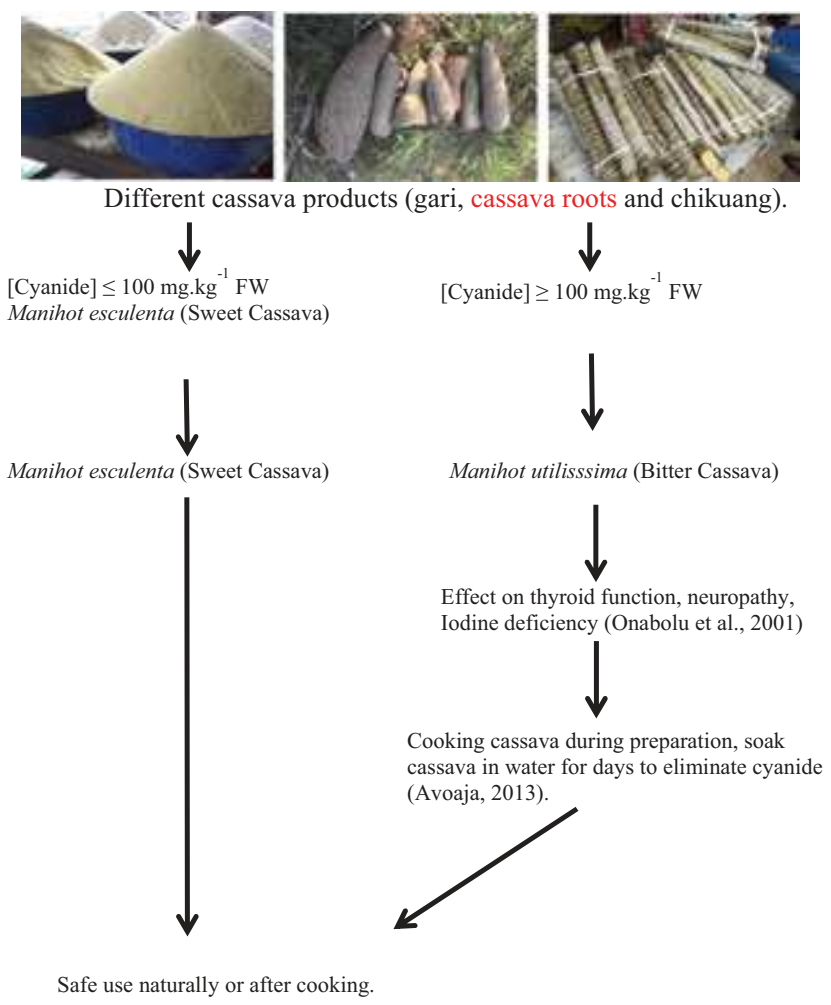

Fig. 2 Cassava preparation before consumption to avoid the risk of exposure to cyanide. By Mombo et al. (2016)
(Bellotti et al. 1999). Global cassava production increased to around 230 million $t$ in 2009-2010 (Zhu et al. 2015). Its production reached 276.7 million $t$ in 2013 (Latif and Müller 2015). It is expected that the annual production of cassava may increase to 291 million t by 2020 (Scott et al. 2000). Of the total cassava production, Africa accounts for $51.3 \%$, Asia 29.4\%, and Latin America 19.3\% (Bellotti et al. 1999). Cassava roots are consumed by over 500 million people living in the tropics and below the Sahara (Best and Henry 1992; Ano et al. 2013), and nearly one billion people in the world (Sajid and Joachim 2014). The cassava root is part of the main staple foods in Sub-Saharan Africa (Tsegai and Kormawa 2002). In some rural areas in Ghana, the annual cassava consumption is estimated at $153 \mathrm{~kg}$ per year (Adjei-Nsiah and Owuraku 2012), which shows the importance of this food for populations in some parts of the world. In Malawi, cassava consumption increased from $22 \mathrm{~g}$ per capita per day in 1990 to 282 g per capita per day in 2005 (Table 1), while maize consumption decreased over the same period from 345 to $316 \mathrm{~g}$ per capita per day (Cańigueral and Vanaclocha 2010). Thailand is the main cassava-producing country (in terms of quantity) with approximately 40 million $\mathrm{t}$ per year with 60 to $70 \%$ generally for own consumption.

Worldwide, nearly $50 \%$ of annual production of cassava roots is used to extract millions of tons of starch. In India, the deficit area to meet the demand is estimated at over 750,000 ha (Kolind-Hansen and Brimer 2010). Nigeria is the largest producer of cassava starch in terms of crop area, and areas used for growing cassava tripled from 1960 to 1999 (IFAD; FAO 2005) and that country is nowadays strongly increasing its production (Oduwaye et al. 2014). Other central African countries such as Gabon, Cameroon, and Congo are also showing increasing interest in the production and processing of cassava root starch.

Nevertheless, despite its immense importance in the developing world, cassava has always received less attention from

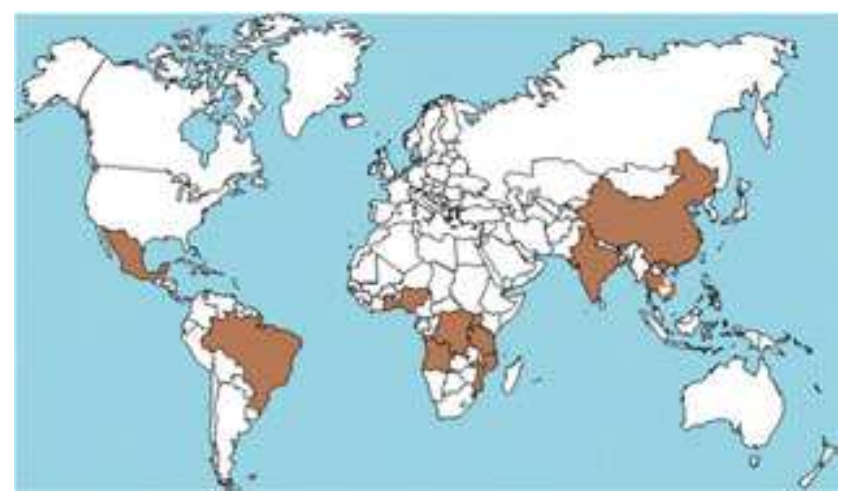

Fig. 3 Cassava-producing countries around the world. Countries that produce cassava are in brown. No information is available for countries in white. By Mombo et al. (2016): sources Bellotti et al. (1999), IFAD and FAO (2005), Kolind-Hansen and Brimer (2010), Latif and Müller (2015), Oduwaye et al. (2014), Scott et al. (2000), and Zhu et al. (2015) 
Table 1 Daily per capita consumption in 2005 of fresh and dried cassava

\begin{tabular}{ll}
\hline Country & Consumption (g) \\
\hline Angola & 787 \\
Mozambique & 680 \\
Democratic Republic of Congo & 653 \\
Congo & 637 \\
Ghana & 546 \\
Liberia & 390 \\
Thailand & 383 \\
Tanzania & 373 \\
Guinea & 352 \\
Central African Republic & 347 \\
Uganda & 328 \\
Benin & 323 \\
Nigeria & 294 \\
Malawi & 282 \\
Togo & 274 \\
Madagascar & 252 \\
Cote d'Ivoire & 237 \\
Cameroon & 233 \\
Indonesia & 146 \\
Brazil & 105 \\
\hline
\end{tabular}

Countries are classified from the highest to the lowest quantities consumed (Nhassico et al. 2008)

researchers than other crops and has earned the status of "orphan crop" (Olsen and Schaal 1999).

Consumption modes, advantages, and natural risks for human nutrition

Cassava is one of the main sources of carbohydrates around the world (Cock (1985), after having been converted into gari, garri kpokpo, flour, foofo, or miondo (Fig. 2), different names are given to cassava flour in various areas of the world (Horsfall et al. 2006)). Cassava root is the fourth most important source of sugar from carbohydrates in the tropics after rice, corn, and sugar cane (Blagbrough et al. 2010). Cassava crops contain more calories per hectare than rice and sorghum.
Indeed, cassava roots are an excellent source of cheap calories for many countries: they represent 50 to $80 \%$ of all calories consumed in some African countries (Nassar and Dorea 1982). The roots of fresh cassava mainly consist of carbohydrates (85-90\%), with a high calorific content of approximately 125 to $140 \mathrm{kcal}$ per $100 \mathrm{~g}$. Table 2 shows daily energy intake from cassava consumption in three countries. In Angola, Tanzania, and Brazil, cassava contributes approximately $1039 \mathrm{cal}$ per day, which is a significant proportion of energy for proper body functioning and health. Daily energy intake in different countries is closely correlated to the amount of cassava consumed per day as shown in Table 2. Daily energy intake in Brazil is almost nine times lower than in Angola and four times less than in Tanzania. This finding confirms that cassava is an important source of carbohydrate intake for low-income countries and for people lacking resources (Nassar and Dorea 1982). A study by IFAD and FAO (2005) showed that in several other African countries, cassava provides $600 \mathrm{kcal}$ per person per day. In the Congo, in the late 1990s, many families ate cassava for breakfast, lunch, and dinner. Cassava contributed more than 1000 cal per person per day (IFAD and FAO 2005) in Congo. It is a staple food for many countries in Africa, south and central west America, Southeast Asia, and India (Zhu et al. 2015). Moreover, even if the cassava stems are not currently used for cooking, Zhu et al. (2015) showed that cassava stems contain a large amount of starch that can be extracted and used. They observed that $87 \%$ of industrial starch used from cassava roots could come from the stem that is not consumable.

Once harvested, cassava deteriorates quickly (1 or 2 days), so it must be quickly eaten or treated (Ceballos et al. 2004). Cassava products (for example, chikuang, gari, or flour), however, (Fig. 2) are long lasting, so they are naturally available throughout the year. The prices of these cassava foods are lower than those of other basic foodstuffs such as rice, maize, sorghum, and millet, which makes it an important food for the lowest social classes (Zhu et al. 2015). In addition, some studies carried out on the nutritional value (especially proteins) of cassava products showed that transformation into flour or fermentation may increase the protein amount due to the action of fungi (Table 3) or microorganisms (Oboh and Akindahunsi 2003). For these reasons, the demand for cassava products

Table 2 Energetic contribution of cassava

\begin{tabular}{clllc}
\hline Countries & $\begin{array}{l}\text { Daily intake of } \\
\text { cassava }\left(\mathrm{g} \mathrm{day}^{-1}\right)\end{array}$ & $\begin{array}{l}\text { Carbohydrate content in } \\
\text { cassava (\%) }\end{array}$ & $\begin{array}{l}\text { Maximum daily carbohydrate } \\
\text { intake of cassava tubers for } \\
\text { an adult }\left(\mathrm{g} \mathrm{day}^{-1}\right)\end{array}$ & $\begin{array}{l}\text { Daily calorie intake } \\
(\text { cal day }\end{array}$
\end{tabular}


Table 3 Percentage of protein in flour and gari after transformation of cassava and mineral composition of fermented cassava products (ppm dry weight)

\begin{tabular}{llllll}
\hline \multirow{2}{*}{ Sample } & \multicolumn{3}{l}{ Flour } & \multicolumn{3}{l}{ Gari } \\
\cline { 2 - 3 } \cline { 5 - 6 } & Unfermented & Fermented & & Unfermented & Fermented \\
\hline Protein & $14.4 \pm 0.1$ & $10.9 \pm 0.1$ & $3.6 \pm 0.1$ & $4.8 \pm 0.1$ \\
Fat & $3.6 \pm 0.1$ & $4.5 \pm 0.2$ & & $2.6 \pm 0.2$ & $34.1 \pm 0.3$ \\
Crude fiber & $3.8 \pm 0.1$ & $3.2 \pm 0.1$ & & $4.3 \pm 0.4$ & $2.8 \pm 0.1$ \\
Carbohydrate & $85.7 \pm 0.1$ & $77.9 \pm 0.3$ & $87.2 \pm 0.2$ & $13.8 \pm 0.1$ \\
Ash & $2.1 \pm 0.1$ & $3.5 \pm 0.1$ & $1.9 \pm 0.2$ & $30.8 \pm 0.1$ \\
Zn & $13.1 \pm 0.1$ & $4.9 \pm 0.2$ & & $5.8 \pm 0.1$ & $4.8 \pm 0.1$ \\
$\mathrm{Mg}$ & $43.4 \pm 0.2$ & $32.4 \pm 0.2$ & $27.7 \pm 0.5$ & $34.1 \pm 0.3$ \\
$\mathrm{Fe}$ & $26 \pm 0.4$ & $2.2 \pm 0.1$ & & $2.3 \pm 0.1$ & $2.8 \pm 0.1$ \\
$\mathrm{Ca}$ & $61.6 \pm 0.7$ & $11 \pm 0.1$ & & $16.7 \pm 0.2$ & $13.8 \pm 0.1$ \\
$\mathrm{Na}$ & $43.8 \pm 0.3$ & $29.6 \pm 0.2$ & $51.4 \pm 0.3$ & $30.8 \pm 0.1$ \\
$\mathrm{~K}$ & $49.8 \pm 0.4$ & $38.4 \pm 0.3$ & $55.6 \pm 0.4$ & $36.9 \pm 0.1$ \\
\hline
\end{tabular}

Source: Oboh and Akindahunsi (2003)

continues to increase regularly at the global scale. Additionally, the demand from Europe for starch, cassava chips, and cassava flour is still growing. In Brazil, 70 to $80 \%$ of cassava production is devoted to the manufacture of flour.

Cassava roots contain only low amounts of lipids and proteins (Nassar and Dorea 1982; Ngudi et al. 2002; Avoaja et al. 2013). Thus, consumption of cassava roots must be associated with other food enriched in proteins and fat to provide a balanced diet. Cassava leaves, however, do contain high amounts of proteins and are an important part of the diet available throughout the year in several countries (Moyo et al. 1998). Crude protein content in cassava leaves typically ranges from 20 to $30 \%$ dry weight (Gomez and Valdivieso 1984; Montagnac et al. 2009). In central Africa and specifically in Congo and Gabon, cassava is therefore considered a complete diet because the roots are used for "bread" as an important source of glucose, and protein-rich leaves are considered "meat" (Achidi et al. 2005). Combined consumption of both tubers and leaves is therefore a sustainable balanced diet that could be further widely developed in other countries.

Another important characteristic of cassava plants is the presence of potentially toxic hydrocyanic acid (HCN) in roots depending on the cultivar. Cyanogenic glycoside toxin is naturally found in cassava roots (and also in fresh bamboo shoots), so it is essential to cook them prior to canning or consumption. According to the OECD (2016), a glucoside content of less than (sweet) or greater than (bitter) $100 \mathrm{mg}$ per kilogram fresh weight is used for the classification of sweet (M. esculenta) and bitter cassava (Manihot utilissima Pohl). Other authors previously proposed three groups for cassava classification: sweet varieties $\left(<50 \mathrm{mg} \mathrm{kg}^{-1}\right)$, intermediate varieties (50$\left.100 \mathrm{mg} \mathrm{kg}^{-1}\right)$, and bitter varieties (>100 $\mathrm{mg} \mathrm{kg}^{-1}$ ) (Nambisan 2011; Guédé 2013). In the present paper, we will talk about sweet and bitter cassava using the OECD definitions. According to Dórea (2004), the bitter cassava variety has a much higher concentration of glucosides (between 320 and $1120 \mathrm{mg} \mathrm{g}^{-1}$ ) than the sweet variety (range 27 to $77 \mathrm{mg} \mathrm{g}^{-1}$ ) (Fig. 2). The two types of cassava are currently consumed. However, due to the toxicity of cyanide, cases of irreversible leg paralysis especially in children have been observed in Mozambique, Tanzania, Congo, and Cameroon and possibly other countries of tropical Africa. In addition to a bitter taste, cyanogenic glucosides such as lotaustralin and linamarin can be toxic. The linamarin glucoside, 2-( $\beta$-D-glucopyranosyloxy) isobutyronitrile, can be broken down by microbial flora in the human intestine and can promote the release of hydrogen cyanide (Kamalu 1995; Carlsson et al. 1999). A few cases of acute intoxication leading to death were also observed (Cańigueral and Vanaclocha 2010).

According to Dórea (2004), indigenous people in the Amazon have developed appropriate technologies that allow them to consume large quantities of these cassava roots throughout their lives without ever having any discernible adverse effects. However, studies in Africa have shown that high consumption of cassava in poor areas was strongly associated with endemic neuropathy and also an increase in iodine deficiency disorders (Onabolu et al. 2001). HCN can be removed by baking or by fermentation in water for a certain period before processing (Avoaja et al. 2013). Baking sweet cassava reduces the cyanide content to non-toxic levels. However, bitter cassava contains more toxins and should be prepared and cooked properly before being consumed. Soaking grated cassava roots in water for a prolonged period leaches cyanide and reduces toxin levels. Cooking further detoxifies the roots before consumption.

\section{Cropping practices}

Cassava crops provide good yields even on poor land (Voko and Zeze 2013). Cassava can also be cultivated in extreme weather conditions such as high rainfall or extreme drought (Voko and Zeze 2013). In Africa, it is mainly cultivated in forest and savanna areas, using indigenous agricultural methods. The soil receives little preparation, and sometimes, it is just cleared by burning. Cassava can withstand significant temperature variations between 16 and $38{ }^{\circ} \mathrm{C}$ allowing its cultivation in a wide diversity of ecosystems (Keating and Evenson 1979; Cock 1985). However, the ideal annual temperature for growth and optimal production was reported to be between 25 and $29{ }^{\circ} \mathrm{C}$ (Conceicao 1979), between 
latitudes $30^{\circ} \mathrm{N}$ and $30^{\circ} \mathrm{S}$ and levels up to $1800 \mathrm{~m}$ above sea level (Ceballos et al. 2004). Germination and yield decrease below $20{ }^{\circ} \mathrm{C}$ (Keating and Evenson 1979). Cassava can also withstand wide $\mathrm{pH}$ variations between 4.5 and 8 as observed by Islam et al. (1980). Although it has few water requirements for optimum production, rainfall should generally be above $700 \mathrm{~mm}$ per year (El-Sharkawy et al. 1992).

Cassava crops are easy to maintain and require only two to three weedings per year. Cassava requires very little or no fertilizer. During its early stage of growth, it can be grown with other crops such as corn, peanut, sesame, millet, or beans (Isabirye et al. 2007). Cassava is an annual plant. The cassava roots can be stored in the ground for several additional months making it an accessible food almost throughout the year. Some cassava varieties are mature after 6 months, and a few varieties can mature after a year for cuttings planted at the same time (Isabirye et al. 2007). All these characteristics explain its increased expansion at the expense of other crops such as maize, yam, or taro that require much more work and nutrients in the soil (Zhang et al. 2003). However, the fact that cassava can be grown even on poor soils will tend to favor its expansion, reducing sometimes plant biodiversity in these areas (Oshunsanya 2016). Finally, in the context of sustainable food, it appears optimal for poor populations to produce a part of their food just near the areas where they live. Cultivation of cassava can be an important and sustainable practice in this regard.

\section{Other uses}

Cassava is now also used for ethanol production. Approximately 2801 of $96 \%$ pure ethanol can be produced from $1 \mathrm{t}$ of cassava, with a starch content of $30 \%$. Several studies have shown the superiority of cassava over maize for biofuel production (Zhang et al. 2003; Dai et al. 2006). Other studies have concluded that ethanol from cassava was significantly better in terms of energy efficiency than that produced from maize (Jakrawatana et al. 2015). Ethanol production from cassava is about $6717 \mathrm{~L} \mathrm{ha}^{-1}$ compared to $3880 \mathrm{~L} \mathrm{ha}^{-1}$ for corn (Ziska et al. 2009). Cassava also needs much less inputs and water than maize (Dai et al. 2006). There are also several other useful cassava products such as confectionery, sweeteners, glues, plywood, textiles, paper, biodegradable products, monosodium glutamate, and drugs (Braide and Adetoro 2013; Igbinosa 2015; Tonukari et al. 2015). In the textile industry, starch is used for sizing cotton yarn before weaving. Maize starch is the major competitor of cassava starch for use during sizing (Srinivas 2007). Because of its good adhesive properties, cassava starch has become an important raw material in the adhesives sector.
Cassava contamination, phytotoxicity, and consequences on human health

Plant contamination by metallic trace elements and phytotoxicity

General overview of cassava plant contamination Even though cassava is a staple food crop in many countries, very few studies have investigated cassava contamination and the impacts on plants and consumers. The majority of cassava is directly consumed or sold by small producers in countries where environmental health regulations are much less well developed than in Europe. Although soil or atmospheric pollution and transfer to ecosystems have been well documented for numerous commercialized plants, cassava crops are not extensively studied. In this section, we will describe how pollution can affect cassava crops and the potential risks using information from available publications.

Several sources of pollution such as cement factories, battery recycling factories, industries, agriculture, and road traffic can be major causes of environmental contamination by TME in the areas where large cassava crops are grown (Kalafatoğlu et al. 2001; El-Abssay and Hassanien 2011; Schreck et al. 2011; Goix et al. 2015; Austruy et al. 2016). Actually, lead, cadmium, mercury, arsenic, and antimony are (eco)toxic TME currently observed in the environment worldwide (Shahid et al. 2015a). Several TME such as Al, Be, Cr, Cu, Mn, Ni, $\mathrm{Pb}$, and $\mathrm{Zn}$, among others, have been identified in fallout from cement plants in several African countries located near cassava fields (Schuhmacher et al. 2002). Figure 4 illustrates the general pathway of pollution transfer from atmospheric fallouts and the facts discussed in this review: contamination of cassava, phytotoxicity, and human bioaccessibility. When TME-polluted cassava is eaten by animals or humans, it may cause severe health problems (Demir et al. 2005). Serious systemic health problems can result from excessive dietary accumulation of heavy metals such as $\mathrm{Cd}$ and $\mathrm{Pb}$ in the human body (Oliver 2008).

Soil-cassava transfer of metal(loid)s and consequences on pollutant accumulation in the plant Kalagbor and Opusunju (2015) reported high levels of heavy metals (Ni, $\mathrm{Zn}, \mathrm{Cu}, \mathrm{Pb}$, and $\mathrm{Fe}$ ) in cassava and plantain compared with FAO/WHOrecommended values from farmlands in Kaani and Kpean, Nigeria. Hart et al. (2005) also found higher concentrations of $\mathrm{Pb}$, iron ( $\mathrm{Fe}), \mathrm{Cu}$, and $\mathrm{Zn}$ in five crops (cassava, cocoyam, okra, pumpkin, and water leaf) harvested from areas with high industrial activity compared to the non-industrialized area of Port Harcourt city in Nigeria. Similar studies carried out by Nkwocha et al. (2011) revealed heavy metal concentrations higher than the permissible WHO value in tuber crops (cassava, plantain, and cocoyam) cultivated in farmland around the Elelebu oil flow station in Bayelsa state, Nigeria. 
Fig. 4 General pathways for pollutant transfer in soil-plantatmosphere systems. TME trace metal element. By Mombo et al. (2016)

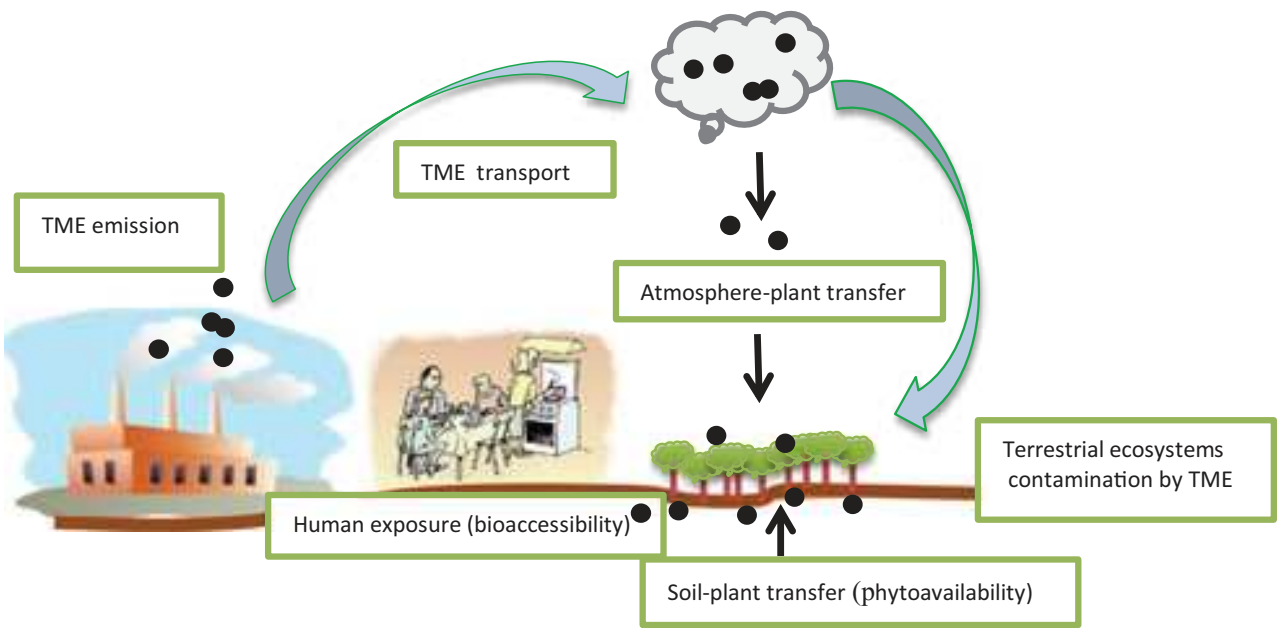

Idodo-Umech and Ogbeibu (2010) also reported that heavy metal concentrations in cassava roots grown in petroleumimpacted soil Olomoro (south local Government Area, delta State Nigeria) were significantly higher than in those grown in reference non-impacted soils. In addition, a few publications examined the use of cassava as a bioaccumulator and their results are quite contrasting. For example, Idodo-Umech and Ogbeibu (2010) concluded that cassava could be considered as a bioaccumulator for some metals such as $\mathrm{Fe}, \mathrm{Zn}, \mathrm{Pb}$, and $\mathrm{Mn}$. They reported that the concentrations of these metals in cassava roots grown in petroleum-impacted soil were significantly higher than those in the corresponding control soil. They also observed that metal concentrations in the cassava strongly depended on the concentration in the soil and that the concentrations varied between the different parts of the plant as observed by Mombo et al. (2016). Similarly, Krríbek et al. (2014) also reported higher concentrations of various metals $(\mathrm{Cu}, \mathrm{Co}, \mathrm{Zn}, \mathrm{As}$, and $\mathrm{Pb})$ in cassava leaves than in stems and roots. Concentration of these metals in leaves was also higher than their concentrations in the soil. However, in contrast, Adjei-Nsiah and Owuraku (2012) concluded that metal concentrations in cassava leaves were lower than in the soil. They suggested that cassava leaves falling on the soil enrich the soil with nitrogen, phosphorus, and metals during their biodegradation by microorganisms. These contrasting findings could arise from the varieties of cassava studied, the age of the crop, the season studied (dry or rainy), type of heavy metals, etc.

\footnotetext{
Atmosphere-cassava transfer of metal(loid)s and consequences in terms of pollutant accumulation in the plant Another, sometimes very significant, way for plant contamination is the atmosphere-plant transfer of metals (Mombo et al. 2015). Actually, atmospheric transfer is very important for phyto-accumulation of metals when plants are exposed to fallout such as fine particles enriched with metals. Indeed, Xiong et al. (2014a) measured $310 \mathrm{mg} \mathrm{Pb} \mathrm{kg}^{-1}$ (dry weight)
}

in parsley, which had only been exposed for a few weeks to a contaminated atmosphere.

Considering that in many countries, cassava leaves are consumed for their protein content and that these are also frequently exposed to aerial metal contamination (factories, roads...), it is important to increase our knowledge on cassava quality in relation to environmental characteristics considering soil, atmosphere, and water quality. Actually, high concentrations of metals in cassava leaves consumed in several parts of Africa and Asia (Achidi et al. 2005) can be due to high atmospheric pollution in these areas. Moreover, studies in this area also showed that metal concentrations in the leaves decrease in the rainy season and increase in the dry season (Chukwuma 1995). The problem of air pollution by particulate matter containing heavy metals (anthropogenic: motor vehicles, biomass, fossil fuel burning and natural sources: windblown soils and sea spray) has recently became a threat to plant quality (Bilen 2010; Xiong et al. 2014a; Leveque et al. 2014). Atmosphereplant transfer depends on the plant species and leaf area; this should be of major concern because of the potential risks to local inhabitant health (Adriano 2001). The main source of environmental contamination in regard to cement production is related to the emission of dust and gas (Bilen 2010; Hindy et al. 1990). Several recent studies concerning TME transfer in plants and their human bioaccessibility have revealed serious risks associated with growing food crops in areas of high atmospheric micronic and sub-micronic particle pollution (Uzu et al. 2009; Mombo et al. 2016). Edori et al. (2015) reported that automobile exhaust emissions and roadside sediments (due to high heavy metal contents in soil) are the most likely sources of heavy metals in gari.

Phytotoxicity Excessive accumulation of heavy metals in plants via both root (soil-plant) and foliar (atmosphere-plant) uptakes was reported to induce a range of phytotoxic effects, which can be biochemical, physiological, or morphological (Shahid et al. 2015b). These effects include reduced seed 
germination, root elongation, biomass, and inhibition of chlorophyll biosynthesis (Pourrut et al. 2011; Austruy et al. 2014). Heavy metal phytotoxicity in plants depends on numerous physiological and molecular functions of the metal and crop, such as the following: (i) uptake and binding to root exudates and cell wall constituents; (ii) chelation and complexation of metal ions by various substances such as phytochelatins, glutathiones, metallothioneins, amino acids, and organic acids; and (iii) activation of plant defense systems for proper functioning of metabolic pathways (Shahid et al. 2013). At present, very little data are available regarding the effect of heavy metals on cassava.

As many high-yielding, disease-resistant varieties of cassava have been developed in Africa, Ano et al. (2013) evaluated the effect of three heavy metals $(\mathrm{Ni}, \mathrm{Pb}$, and $\mathrm{Cd}$ ) applied at four rates $\left(0,100,200\right.$, and $\left.300 \mathrm{mg} \mathrm{kg}^{-1}\right)$ on five improved cassava varieties (TMS 97/2205, TMS 98/0510, TME 419, TMS 98/0505, and TMS 98/0581) (Table 4). They observed that heavy metals significantly reduced sprouting, root weight, root length, stem girth, and dry matter yield of the cassava. They concluded that the reduced germination and growth of cassava exposed to the metals were related to reduced water absorption by the roots (Table 5). Indeed, metals are well known to physiologically block the absorption of water during seed germination and plant growth (Azmat et al. 2006). They also reported that the effect and extent of the influence of the heavy metals varied with cassava variety and metal type. A steady reduction in the number of cassava leaves on the four varieties exposed to $\mathrm{Cd}$ and $\mathrm{Ni}$ at 100 and $300 \mathrm{mg}$, respectively, was also observed, whereas $\mathrm{Pb}$ exposure had no effect on the number of cassava leaves at these same concentrations (Table 5). Similarly, Ryser and Sauder (2006) observed that a delay in the growth of Hieracium pilosella L. decreased leaf numbers and also a decrease in life duration after exposure to the TME.

\section{Risks of consuming cassava grown in polluted areas and natural cassava toxicity}

Risks of consuming cassava grown in polluted areas In a recent study carried out in the Nigerian city of Port Harcourt, Edori et al. (2015) reported that in gari (cassava powder) sold on the roadside, concentrations of $\mathrm{Fe}, \mathrm{Zn}, \mathrm{Cd}$, and $\mathrm{Cr}$ were higher than the daily doses of trace metals allowed in food by the Food and Agriculture Organization (FAO). For example, the Fe concentration $\left(39.8 \mathrm{mg} \mathrm{kg}^{-1}\right)$ was more than twice the daily allowable dose of the FAO (15 mg day $\left.{ }^{-1}\right)$. The concentrations of $\mathrm{Cd}$ and $\mathrm{Cr}$ (0.04 and $0.14 \mathrm{mg} \mathrm{kg}^{-1}$, respectively) were also higher than the FAO-recommended daily concentrations for these two elements $\left(1.5 \mathrm{mg} \mathrm{day}^{-1}\right) . \mathrm{Cd}$ and $\mathrm{Cr}$ also showed high bioaccumulation factors (26 and 93, respectively), certainly responsible for significant damage to human health (Edori et al. 2015).

Human exposure to heavy metals can occur through several pathways (Uzu et al. 2014), but the main way remains food consumption (Xiong et al. 2014c). Human exposure and the health impacts of cassava ingestion may essentially depend on the mode (roots, powder, etc.) of cassava consumption, the quantities consumed, and the geographic zone considered, that is to say, the local context of contamination. Cassava consumption largely differs worldwide, especially depending on the considered countries and regions. In the present review, we have focused on cassava consumption as roots in Africa (Nigeria), as the main way of potential human exposure to TME. Most of the studies on cassava contamination by TME reported an accumulation of $\mathrm{Cd}, \mathrm{Pb}$, and $\mathrm{Zn}$; therefore,

Table 4 Effect of trace metal elements (Cd, Ni, and $\mathrm{Pb}$ ) on percentage sprouting of cassava on five different cassava varieties (TME 419, TMS 98/ 0505, TMS 98/0510, TMS 98/0581, and TMS 97/2205)

\begin{tabular}{|c|c|c|c|c|c|c|c|c|}
\hline \multicolumn{9}{|c|}{ Percentage sprouting of cassava (\%) } \\
\hline \multirow[t]{2}{*}{ Metal } & \multirow{2}{*}{$\begin{array}{l}\text { Rate of application } \\
\left(\mathrm{mg} \mathrm{kg}^{-1} \text { soil }\right)\end{array}$} & \multicolumn{5}{|c|}{ Cassava variety } & \multirow[t]{2}{*}{ Mean $(\%)$} & \multirow[t]{2}{*}{ SE } \\
\hline & & TME 419 & TMS 98/0505 & TMS 98/0510 & TMS 98/0581 & TMS 97/2205 & & \\
\hline \multirow[t]{3}{*}{$\mathrm{Cd}$} & 100 & 100 & 66.7 & 100 & 66.7 & 66.7 & 80 & 8.6 \\
\hline & 200 & 66.7 & 100 & 100 & 100 & 100 & 3.4 & 20.36 \\
\hline & 300 & 66.7 & 100 & 66.7 & 100 & 66.7 & 2.4 & 40.82 \\
\hline \multirow[t]{3}{*}{$\mathrm{Ni}$} & 100 & 100 & 33.3 & 33.3 & 100 & 66.7 & 66.7 & 14.66 \\
\hline & 200 & 100 & 100 & 0 & 100 & 66.7 & 2 & 28.93 \\
\hline & 300 & 100 & 100 & 33.3 & 100 & 0 & 1 & 46.59 \\
\hline \multirow[t]{3}{*}{$\mathrm{Pb}$} & 100 & 66.7 & 100 & 33.3 & 100 & 33.3 & 3.8 & 14.66 \\
\hline & 200 & 100 & 100 & 66.7 & 100 & 0 & 4 & 28.93 \\
\hline & 300 & 100 & 66.7 & 33.3 & 100 & 33.3 & 66.7 & 44.64 \\
\hline
\end{tabular}

Source: Ano et al. (2013) 
Table 5 Effect of trace metal elements $(\mathrm{Cd}, \mathrm{Ni}$, and $\mathrm{Pb})$ on number of cassava leaves per plant

\begin{tabular}{|c|c|c|c|c|c|c|c|c|}
\hline \multicolumn{9}{|c|}{ Number of cassava leaves plant } \\
\hline \multirow[t]{2}{*}{ Heavy metal } & \multirow{2}{*}{$\begin{array}{l}\text { Rate of application } \\
\left(\mathrm{mg} \mathrm{kg}^{-1} \text { soil }\right)\end{array}$} & \multicolumn{5}{|c|}{ Cassava variety } & \multirow[t]{2}{*}{ Mean } & \multirow[t]{2}{*}{ SE } \\
\hline & & TME 419 & TMS 98/0505 & TMS 98/0510 & TMS 98/0581 & TMS 97/2205 & & \\
\hline \multirow[t]{3}{*}{$\mathrm{Cd}$} & 100 & 1 & 7 & 3 & 5 & 0 & 3.2 & 17.71 \\
\hline & 200 & 1 & 5 & 3 & 6 & 2 & 3.4 & 35.9 \\
\hline & 300 & 3 & 3 & 2 & 4 & 0 & 2.4 & 54.34 \\
\hline \multirow[t]{3}{*}{$\mathrm{Ni}$} & 100 & 3 & 6 & 2 & 4 & 5 & 4 & 17.54 \\
\hline & 200 & 4 & 2 & 0 & 3 & 1 & 2 & 36.15 \\
\hline & 300 & 1 & 3 & 0 & 2 & 0 & 1 & 54.55 \\
\hline \multirow[t]{3}{*}{$\mathrm{Pb}$} & 100 & 4 & 5 & 3 & 5 & 1 & 3.8 & 17.58 \\
\hline & 200 & 4 & 4 & 4 & 1 & 2 & 4 & 35.79 \\
\hline & 300 & 2 & 6 & 2 & 0 & 4 & 4 & 55.98 \\
\hline
\end{tabular}

Source: Ano et al. (2013)

we have chosen $\mathrm{Pb}, \mathrm{Zn}$, and $\mathrm{Cd}$ as examples for exposure calculations and a risk assessment.

In order to assess the impact of metal pollutants on human health after cassava ingestion, daily intake (DI, $\mu \mathrm{g} \mathrm{day}{ }^{-1}$ ) can be estimated from the measured TME concentrations in plant tissues. The following equation (Eq. 1) is generally used to calculate the DI of metal (Cui et al. 2004; Sharma et al. 2009; Okorie et al. 2012):

Daily intake of metal (DI, $\mu \mathrm{g} \mathrm{kg}{ }^{-1}$ day $\left.^{-1}\right)=$ cassava metal concentration $\left(\mu \mathrm{g} \mathrm{g}^{-1}\right.$ of FW)

$$
\times \text { daily cassava consumption (g per day)/body weight }(\mathrm{kg})
$$

In order to calculate a possible $\mathrm{DI}$ of $\mathrm{Pb}, \mathrm{Cd}$, and $\mathrm{Zn}$ in cassava, we considered the concentrations of these metals reported by Onyedika and Nwosu (2008) in Amazonia, Nigeria $\left(0.08,1.890\right.$, and $1.070 \mu \mathrm{g} \mathrm{g}^{-1}$ of dry weight (DW) for $\mathrm{Pb}, \mathrm{Zn}$, and $\mathrm{Cd}$, respectively). Heavy metal concentrations per DW were converted into concentrations per fresh weight $(\mathrm{FW})$ : (percentage of dry matter in the sampled plant tissue) $\times$ (average water content at $25 \%$ for cassava roots) (Hoover 2001). The average daily consumption of cassava per person may vary depending on the considered country (Table 1). Generally, in Africa, the mean DI of cassava is approximately 294 g per capita per day as, for example, in Nigeria (Cańigueral and Vanaclocha 2010). However, those values decrease highly in Europe as flour and chip consumption (Kolind-Hansen and Brimer 2010).
Average body weights in Nigeria are estimated as $64 \mathrm{~kg}$ for women and $72 \mathrm{~kg}$ for men (Ehimwenma and Tagbo 2011). So, an average of $68 \mathrm{~kg}$ of body weight for an adult in Nigeria was then chosen for risk assessment.

The determined DI values were then compared to tolerable daily intake (TDI, $\mu \mathrm{g} \mathrm{kg}^{-1} \mathrm{day}^{-1}$ ) expressed as the quantity of metal ingested each day $(\mu \mathrm{g})$ as a function of kilogram body weight. The TDI values were established by assessing urban impacted soil for urban gardening Toronto Health 2011 at 100; 15,000; and $0.5 \mu \mathrm{g} \mathrm{kg}^{-1} \mathrm{day}^{-1}$, respectively, for $\mathrm{Pb}, \mathrm{Zn}$, and $\mathrm{Cd}$.

The maximum daily quantities of cassava consumed in Africa to reach the TDI for each TME can therefore be calculated with Eq. 2:

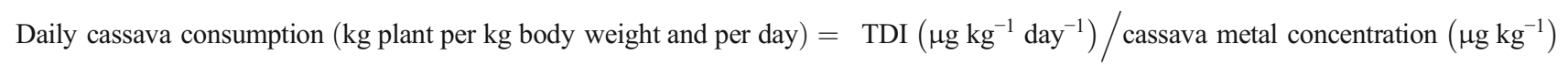


The maximum quantity of cassava contaminated by TME (i.e., $\mathrm{Pb}, \mathrm{Zn}$, and $\mathrm{Cd}$ in Nigeria) that can be consumed daily without exceeding the TDI is given in Table 6. The results showed that there is no risk associated with cassava consumption for $\mathrm{Pb}$ and $\mathrm{Zn}$ in this area. However, the consumption of $294 \mathrm{~g} \mathrm{day}^{-1}$ of cassava contaminated with $\mathrm{Cd}$ could have negative effects on health in this area. This is because the maximum quantity of Cd-exposed cassava roots, which can be safely consumed by an adult of $68 \mathrm{~kg}$, is less than $1.9 \mathrm{~g} \mathrm{day}^{-1}$. Cadmium is classified as a type I carcinogen species by the International Agency for Cancer Research (Souza-Arroyo et al. 2012) especially because of its high bioaccumulation (Xiong et al. 2014a; Mombo et al. 2015). Another study reported increasing mortality of populations living in Cd-polluted areas (Iwata et al. 1992). This shows that extreme care should be taken in the case of $\mathrm{Cd}$ due to its high bioavailability and toxicity (Valko et al. 2015). Thus, these results suggest possible exposure and toxicity for people who consume cassava grown in the vicinity of mining areas, recycling factories, or also roads (Xiong et al. 2016).

Natural cassava toxicity (hydrogen cyanide) Although cassava is a food with many nutritional benefits, it can also be detrimental to human health as explained by Onabolu et al. (2001): out of 1272 individuals living in different parts of Nigeria where the staple food is cassava, more than $60 \%$ had high thiocyanate concentrations (certainly originating from cyanide in bitter cassava). Cyanide is a highly effective poison for animals, insects, and plants. More than 2000 plants use cyanide to protect against marauding animals and insects (Jones 1998). Plants, such as cassava, first produce glucoside cyanogen, which is then transformed into hydrogen cyanide (HCN) (White 1998). The lethal oral dose of HCN for a $60-\mathrm{kg}$ adult is 30-210 mg. According to Nhassico et al. (2008), cyanogen glucoside content in cassava roots and leaves is very dangerous to human health and can, in extreme situations, produce acute intoxication that can lead to death. It is responsible for the "Kenzo anomaly" that leads to neuropathy and delay in growth of some children in several African countries including tropical Mozambique, Tanzania, Democratic Republic of Congo, Cameroon, and Central African
Republic. Kenzo anomaly in children is responsible for irreversible paralysis of the legs, with thousands of cases in the previously mentioned countries (Nhassico et al. 2008). A study conducted by Dhas et al. (2011) on people who had worked in a cassava-processing plant for 5 years found that it had an impact on their thyroid glands with insufficient iodine uptake as well as kidney and liver malfunction. Before consumption, methods can be used to decrease the amount of cyanide in the cassava. According to the FAO (1991), an efficient processing method releases linamarase, which disintegrates the microstructure of the cassava root. The liberated cyanide dissolves in water when prolonged soaking causes fermentation. Soaking in water also improves detoxification since the cells are broken by osmosis and fermentation, which facilitates the hydrolysis of the glycosides. Compressing the product is a fundamental step in the removal of soluble cyanide. A short soak ( $4 \mathrm{~h}$ ) has no effect, but if prolonged (18 to $24 \mathrm{~h}$ ), the amounts of cyanide can be halved or even reduced by more than six times when soaked for several days (Nhassico et al. 2008). Thus, this is a simple and highly recommended procedure for safe consumption.

\section{Environmental benefits of cassava cropping}

\section{Biological agriculture and citizen information}

Cassava is a robust plant, able to achieve optimal average production in diverse land types without agricultural inputs (fertilizers or pesticides). Other significant strengths of cassava are as follows: its low water requirements and ability to resist against pests (Bellotti and Arias 2001). Thus, cassava has many real benefits over more demanding (expensive to grow) crops that are less tolerant to different soil types, latitudes, and environments, and it is also environmental friendly. Given its reliability and productivity, cassava has a unique and important position as a food security crop for smallholder farmers especially in tropical regions where climate, soil, or societal constraints limit crop production and do not often allow cultivation of a large variety of crops. In addition, with global warming, in the near future, this plant could be grown in larger areas. Currently, the pressure on food production and

Table 6 Calculated maximum daily quantities of cassava tuber exposed to metals ( $\mathrm{g}$ day ${ }^{-1}$, dry weight) that can be consumed without exceeding the TDI

\begin{tabular}{lllcc}
\hline Metal & $\begin{array}{l}\text { Daily intake of } \\
\text { cassava }\left(\mathrm{g} \mathrm{day}^{-1}\right)\end{array}$ & $\begin{array}{l}\text { Daily intake of metals } \\
\left(\mathrm{DI}, \mu \mathrm{g} \mathrm{kg}^{-1} \mathrm{day}^{-1}\right)\end{array}$ & $\begin{array}{l}\text { Tolerable daily intake } \\
\left(\mathrm{TDI}, \mu \mathrm{g} \mathrm{kg} \mathrm{day}^{-1}\right)\end{array}$ & $\begin{array}{l}\text { Maximum daily quantity of } \\
\text { cassava tubers exposed to metal } \\
\left.\text { for an adult of } 68 \mathrm{~kg}(\mathrm{~g} \mathrm{day})^{-1}\right)\end{array}$ \\
\hline $\mathrm{Pb}$ & 294 & 0.09 & 100 & 5000 \\
$\mathrm{Zn}$ & 294 & 2.04 & 15,000 & 31,746 \\
$\mathrm{Cd}$ & 294 & 1.16 & 0.5 & 1.9 \\
\hline
\end{tabular}


supply is increasing due to the increase in the global population. Rapid increases in population size, urbanization, and industrialization are leading to a decrease in available agricultural land and enhanced energy demand. The world's population is expected to increase between now and 2050 by more than two billion (Zhu et al. 2015), and it is becoming increasingly difficult to sustain the whole population. Sustainable crop production with food crops that can be grown on marginal land with low requirements, such as nutritive cassava, is therefore one of the crucial goals of modern agricultural systems. This type of crop appears ideal for supporting increasing populations and concerns in terms of the environment, human health, and reducing ecological inequalities.

In urban areas, however, atmospheric and soil pollutions are often observed, mainly due to the proximity of roads and agricultural and industrial activities which have been going on for centuries (Shahid et al. 2012; Mitchell et al. 2014). Indeed, many pollutants can flow or accumulate in the atmosphere, water, soil, and finally vegetables (Uzu et al. 2014; Pierart et al. 2015; Clinard et al. 2015). Marketed plants are regulated in Europe with respect to some targeted inorganic pollutants such as $\mathrm{Pb}, \mathrm{Cd}$, and $\mathrm{Hg}$ (EC, no. 466/2001) (Mortureux 2012). In France, for example, the potentially most polluting anthropogenic activities are managed by the "ICPE" regulation (http://www.installationsclassees.developpement-durable. gouv.fr/accueil.php), which is a specific regulation to protect the environment and human health. The ICPE regulations specifically impose participation in the "BASIAS" (http://basias.brgm.fr/) and "BASOL" (http://basol. developpement-durable.gouv.fr/) databases, which record activities carried out using regulated plants (classified ICPE in France) and for soil remediation, respectively. A challenge for several countries throughout the world is therefore to develop regulations to reduce the emissions in the environment.

Due to the complexity of the biophysicochemical mechanisms involved in the transfer of substances in terrestrial ecosystems and the numerous interactions occurring, scientists can rarely provide citizens with simple information on the quality of their cultivated plants (Dumat et al. 2015). They need first to carry out surveys, preliminary observations, and dedicate time and money to analyses and recommendations. They often have only a partial view of the ecosystem, and it is therefore difficult to answer with certainty a simple question from a citizen on the impact of pollution. The researcher will often answer: "it depends" on soil characteristics (texture, $\mathrm{pH}$, soil organic matter amount...), crop variety, and practices (Dumat et al. 2015). Promoting practical collaborations between researchers and citizens is therefore a crucial environmental health issue, as millions of citizens cultivate and consume vegetables in the world. How to reconcile scientific research thrusts on the mechanisms involved and practical solutions to improve ecosystem services while increasing initiatives to bring science and society in this direction is an important challenge. This is the case of the participatory research formation network "Reseau-Agriville" (http://reseauagriville.com/), which is an innovative project with shared and free resources concerning urban agriculture. This type of resource can help shape a favorable interface between knowledge and practice in the context of ecological transition at the global scale.

\section{New value-adding cassava by-products: the peel}

Studies on polluted soils showed that cassava peel was enriched with metals (Padmavathiamma and Li 2007). In order to reduce human exposure, it is therefore important to remove the skin. However, interestingly, cassava peel is showing potential as an efficient material for the remediation of wastewaters. Indeed, Bassey et al. (2013) found that soils near artisanal cassava-processing plants and, more specifically, areas around places where cassava peelings were deposited were generally acidic. This acidity is due to the hydrogen cyanide in the cassava peel. It can also be responsible for effluents that are pollution sources (Cock 1985) and factors promoting the mobility of metals. Indeed, the cassava peelings contain sulfhydryl functional groups that can promote thiolating process and immobilize the metal ions (Simate and Ndlovu 2014). This study shows that these functional groups immobilized metal ions before their biosorption. In a context of a circular economy, cassava peelings could thus be used as agents for metal complexation in the context of remediation of polluted soils or wastewater cleaning.

\section{Conclusions and perspectives}

In the context of global warming and population increases, cassava is a promising sustainable food crop because of its multiple advantages: growth on marginal lands, no fertilizer requirements for optimal production, low water requirements, and ability to withstand large temperature variations. Indeed, it grows well at $30 \mathrm{~N}$ and $30 \mathrm{~S}$ latitude and at altitudes ranging from 0 to $1800 \mathrm{~m}$ above sea level in a range of humidity. Its high starch content and production per hectare (compared with other plants) make it a very interesting product in diverse fields including biofuels, textiles, cosmetics, stationery, sweeteners, confectionery, plywood, and many others.

However, the following advice can be given to the general population/farmers/decision makers/stakeholders in order to avoid significant health risks associated with cassava consumption:

1. Sweet cassava should be preferably cultivated, and/or the methods for preparing bitter cassava should be carefully followed. 
2. The diet needs to be varied as much as possible, so carbohydrate-rich cassava should be regularly accompanied by meat or other foods high in protein (cassava leaves).

3. A challenge for numerous countries is to develop regulations to improve air and soil quality in order to safeguard crop quality.

To widely diffuse information on sustainable practices for cultivating and consuming cassava to the general public, a learning resource is available online on the network RéseauAgriville (http://reseau-agriville.com/).

Acknowledgements This work received support from Gabon through "Agence Nationale des Bourses du Gabon" (ANBG) for Mombo PhD funding. The STCM Company is acknowledged for its financial and technical support to the thesis of Mombo S. The authors thank Leigh Gebbie for English revision.

\section{References}

Achidi AU, Ajayi O a, Maziya-dixon B, Bokanga M (2005) The effect of processing on the nutrient content of cassava (Manihot esculenta Crantz) leaves. J Food Process Preserv 32:486-502. doi:10.1111 j.1745-4549.2007.00165.x

Addo MA (2010) Heavy metal contaminations in soil and cassava harvested near a cement processing facility in the Volta Region, Ghana: implications of health risk for the population living in the vicinity. 71-83.

Adjei-Nsiah S, Owuraku S-D (2012) Promoting cassava as an industrial crop in Ghana: effects on soil fertility and farming system sustainability. Appl Environ Soil Sci. doi:10.1155/2012/940954

Adriano DC (2001) Trace elements in terrestrial environments: biogeochemistry, bioavailability and risk of metals. Springer

Ano O, Eke-Okoro N, Egesi N (2013) Heavy metals (Cd, Ni and Pb) pollution effects on cassava (Manihot esculenta Crantz). Int $\mathrm{J}$ Biodivers Conserv 5:640-646

Austruy A, Laplanche C, Mombo S et al (2016) Ecological changes in historically polluted soils: metal(loid) bioaccumulation in microarthropods and their impact on community structure. Geoderma 271:181-190. doi:10.1016/j.geoderma.2016.02.011

Austruy A, Shahid M, Xiong T et al (2014) Mechanisms of metalphosphates formation in the rhizosphere soils of pea and tomato: environmental and sanitary consequences. J Soils Sediments 14: 666-678. doi:10.1007/s11368-014-0862-z

Avoaja D, Eze V, Owunna N (2013) Microbiological and physicochemical characteristics of soil receiving palm oil mill effluent in Umuahia, Abia State, Nigeria. J Nat Sci Res 3:163-170. doi:10.12691/jaem-3-1-4

Azmat R, Saba H, Shabana A (2006) Phyotoxicity of Pb: I effect of Pb on germination, growth, morphology and histomorphology of Phaseolus mungo and Lens culinaris. Pakistan J Biol Sci 9:979984. doi:10.3923/pjbs.2006.979.984

Bassey FI, Tesi GO, Nwajei GE, Tsafe a I (2013) Assessment of heavy metal contamination in soils around cassava processing mills in suburban areas of Delta State, Southern Nigeria $1 *$ C. M. A. J Basic Appl Sci 21:96-104

Bellotti A, Smith L, Lapointe SL (1999) Recent advances in cassava pest management. Annu Rev Entomol 44:343-370. doi:10.1146 /annurev.ento.44.1.343
Bellotti AC, Arias B (2001) Host plant resistance to whiteflies with emphasis on cassava as a case study. Crop Prot 20:813-823. doi:10.1016/S0261-2194(01)00113-2

Best R, Henry G (1992) Cassava: towards the year 2000. In: International Network for Cassava Genetic Resources. In: Report of the First Meeting of the International Network for Cassava Genetics Resources, CIAT, Cali. Colombia. IPGRI, Rome, International Crop Network Series, pp. 3-11

Bilen S (2010) Effect of cement dust pollution on microbial properties and enzyme activities in cultivated and no-till soils. African J Microbiol Res 4:2418-2425

Blagbrough IS, Bayoumi SAL, Rowan MG, Beeching JR (2010) Cassava: an appraisal of its phytochemistry and its biotechnological prospects. Phytochemistry 71:1940-1951. doi:10.1016/j. phytochem.2010.09.001

Braide O, Adetoro S (2013) Cassava flour as a resin printing paste for textile patterns, Abeokuta, Nigeria. Transnatl J Sci Technol 3:15-29

Burns A, Gleadow R, Cliff J et al (2010) Cassava: the drought, war and famine crop in a changing world. Sustainability 2:3572-3607. doi:10.3390/su2113572

Burns AE, Bradbury JH, Cavagnaro TR, Gleadow RM (2012) Total cyanide content of cassava food products in Australia. J Food Compos Anal 25:79-82. doi:10.1016/j.jfca.2011.06.005

Cańigueral S, Vanaclocha B (2010) Revista de Fitoterapia: editorial. Rev Fitoter 10:103. doi:10.1002/jsfa

Carlsson L, Mlingi N, Juma a et al (1999) Metabolic fates in humans of linamarin in cassava flour ingested as stiff porridge. Food Chem Toxicol 37:307-312. doi:10.1016/s0278-6915(99)00015-0

Ceballos H, Iglesias C a, Pérez JC, Dixona GO (2004) Cassava breeding: opportunities and challenges. Plant Mol Biol 56:503-516. doi:10.1007/s11103-004-5010-5

Chukwuma C (1995) A comparative study of cadmium, lead, zinc, pH, and bulk density from the Enyigba lead and zinc mine in two different seasons. Ecotoxicol Environ Saf 31:246-249. doi:10.1006 /eesa. 1995.1070

Clinard F, Delefortrie A, Bellec S et al (2015) Enquête de pratiques agricoles et de consommation alimentaire dans les jardins ouvriers de l'agglomération de Belfort (Franche-Comté). Environnement, Risques \& Santé 14:56-71. doi:10.1684/ers.2014.0754

Cock JH (1985) Cassava: new potential for a neglected crop. IADS devel. Westview Press

Conceicao AJ da . (1979) A mandioca., 3rd edn. EMBRAPA/BNB/ BRASCAN NORDESTE, Texas

Cui YJ, Zhu YG, Zhai RH et al (2004) Transfer of metals from soil to vegetables in an area near a smelter in Nanning, China. Environ Int 30:785-791. doi:10.1016/j.envint.2004.01.003

Dai D, Hu Z, Pu G et al (2006) Energy efficiency and potentials of cassava fuel ethanol in Guangxi region of China. Energy Convers Manag 47:1686-1699. doi:10.1016/j.enconman.2005.10.019

Demir TA, Işikli B, Urer SM et al (2005) Nickel exposure and its effects. Biometals 18:7-13. doi:10.1007/s10534-004-1209-9

Dhas PK, Chitra P, Jayakumar S, Mary AR (2011) Study of the effects of hydrogen cyanide exposure in cassava workers. Indian J Occup Environ Med 15:133-136. doi:10.4103/0019-5278.93204

Dórea JG (2004) Cassava cyanogens and fish mercury are high but safely consumed in the diet of native Amazonians. Ecotoxicol Environ Saf 57:248-256. doi:10.1016/j.ecoenv.2003.12.008

Dumat C, Pierart A, Stockachie L, Borries O, Messina M, Chevalarias F, Cazenave JM, Bertoni G (2015) Socio-scientific strategies for research and formation projects to favor sustainable urban agricultures at the global scale. International Conference on Soils in Urban, Industrial, Traffic, Mining and Military Areas, to be held in Mexico City from Sept 20th till Sept 25th, 2015

Edori OS, Ajuru I, Harcourt P (2015) Analysis of some heavy metals (Pb, $\mathrm{Cd}, \mathrm{Cr}, \mathrm{Fe}, \mathrm{Zn}$ ) in processed cassava flour (garri) sold along the road side of a busy highway. 7:15-19. 
Ehimwenma O, Tagbo MT (2011) Determination of normal dimension of the spleen by ultrasound in an endemic tropical environment. Niger Med J 52:198-203. doi:10.4103/0300-1652.86141

El-Abssay A, Hassanien M (2011) Health risk assessment of workers exposed to heavy metals in Cement Kiln Dust (CDK).

El-Sharkawy MA, Hernández ADP, Hershey C (1992) Yield stability of cassava during prolonged mid-season water stress. Exp Agric 28: $165-174$

FAO. 1991. Racines, tubercules, plantains et bananes: dans la nutrition humaine.

Goix S, Mombo S, Schreck E et al (2015) Field isotopic study of lead fate and compartmentalization in earthworm-soil-metal particle systems for highly polluted soil near $\mathrm{Pb}$ recycling factory. Chemosphere 138: 10-17. doi:10.1016/j.chemosphere.2015.05.010

Gomez G, Valdivieso M (1984) Cassava for animal feeding: effect of variety and plant age on production of leaves and roots. Anim Feed Sci Technol 11:49-55. doi:10.1016/0377-8401(84)90053-1

González AG, Mombo S, Leflaive J et al (2015) Silver nanoparticles impact phototrophic biofilm communities to a considerably higher degree than ionic silver. Environ Sci Pollut Res Int 22:8412-8424. doi:10.1007/s11356-014-3978-1

Guédé SS (2013) Assessment of Cyanide Content in Cassava (Manihot esculenta Crantz) Varieties and Derived Products from Senegal. Int J Nutr Food Sci 2:225. doi:10.11648/j.jinfs.20130205.12

Hart A, Oboh C, Barimalaa I, Sokari T (2005) Concentrations of trace metals (lead, iron, copper and zinc) in crops harvested in some oil prospecting locations in rivers state, Nigeria

Hindy KT, Abdel Shafy HI, Farag SA (1990) The role of the cement industry in the contamination of air, water, soil and plant with vanadium in Cairo. Environ Pollut 66:195-205. doi:10.1016/0269-7491 (90)90001-S

Hoover R (2001) Composition, molecular structure, and physicochemical properties of tuber and root starches: a review. Carbohydr Polym 45: 253-267. doi:10.1016/S0144-8617(00)00260-5

Horsfall M, Abia a a, Spiff a I (2006) Kinetic studies on the adsorption of $\mathrm{Cd} 2+, \mathrm{Cu} 2+$ and $\mathrm{Zn} 2+$ ions from aqueous solutions by cassava (Manihot sculenta Cranz) tuber bark waste. Bioresour Technol 97: 283-291. doi:10.1016/j.biortech.2005.02.016

Huang J, Tichit M, Poulot M et al (2015) Comparative review of multifunctionality and ecosystem services in sustainable agriculture. J Environ Manag 149:138-147. doi:10.1016/j. jenvman.2014.10.020

Idodo-Umech G, Ogbeibu A (2010) Bioaccumulation of the heavy metals in cassava tubers and plantain fruits grown in soils impacted with petroleum and non-petroleum activities. Res J Environ Sci 4:33. doi:10.3923/rjes.2010.33.41

IFAD; FAO (2005) A review of cassava in Africa with country case studies on Nigeria, Ghana, the United Republic of Tanzania, Uganda and Benin. Agric Consum Prot 357

Igbinosa EO (2015) Effect of cassava mill effluent on biological activity of soil microbial community. Environ Monit Assess 187:418. doi:10.1007/s10661-015-4651-y

Isabirye M, Ruysschaert G, Van linden L et al (2007) Soil losses due to cassava and sweet potato harvesting: a case study from low input traditional agriculture. Soil Tillage Res 92:96-103. doi:10.1016/j. still.2006.01.013

Islam AKMS, Edwards DG, Asher CJ (1980) pH optima for crop growth. Plant Soil 54:339-357. doi:10.1007/BF02181830

Iwata K, Saito H, Moriyama M, Nakano A (1992) Follow up study of renal tubular dysfunction and mortality in residents of an area polluted with cadmium. Br J Ind Med 49:736-737

Jakrawatana N, Pingmuangleka P, Gheewala SH (2015) Material flow management and cleaner production of cassava processing for future food, feed and fuel in Thailand. J Clean Prod:1-9. doi:10.1016/j. jclepro.2015.06.139
Jones DA (1998) Why are so many food plants cyanogenic? Phytochemistry 47:155-162. doi:10.1016/S0031-9422(97)00425-1

Kalafatoğlu E, Örs N, Özdemir SS, Munlafalioğlu I (2001) Trace element emissions from some cement plants in Turkey. Water Air Soil Pollut 129:91-100. doi:10.1023/A:1010371019712

Kalagbor IA, Opusunju K (2015) A comparison study of dry and wet ashing methods used for the assessment of concentration of five heavy metals in three vegetables from Rivers State, Nigeria. Int Res J Public Environ Heal 2:16-22

Kamalu BP (1995) The adverse effects of long-term cassava (Manihot esculenta Crantz) consumption. Int J Food Sci Nutr 46:65-93. doi:10.3109/09637489509003387

Keating BA, Evenson JP (1979) Effect of soil temperature on sprouting and sprout elongation of stem cuttings of cassava (Manihot esculenta Crantz.). F Crop Res 2:241-251. doi:10.1016/0378-4290 (79)90026-1

Kolind-Hansen L, Brimer L (2010) The retail market for fresh cassava root tubers in the European Union (EU): the case of Copenhagen, Denmark - a chemical food safety issue. J Sci Food Agric 90:252256. doi:10.1002/jsfa.3804

Kříbek B, Majer V, Knésl I et al (2014) Concentrations of arsenic, copper, cobalt, lead and zinc in cassava (Manihot esculenta Crantz) growing on uncontaminated and contaminated soils of the Zambian Copperbelt. J African Earth Sci 99:713-723. doi:10.1016/j. jafrearsci.2014.02.009

Latif S, Müller J (2015) Potential of cassava leaves in human nutrition: a review. Trends Food Sci Technol. doi:10.1016/j.tifs.2015.04.006

Leveque T, Capowiez Y, Schreck E et al (2014) Earthworm bioturbation influences the phytoavailability of metals released by particles in cultivated soils. Environ Pollut 191:199-206. doi:10.1016/j. envpol.2014.04.005

Li H, Liu Y, Gao X, Li X (2015) Preparation and characterization of cassava starch-based adsorbents for separating of azeotropic ethanol-water in biofuels ethanol production. J Chem Technol Biotechnol n/a-n/a. doi:10.1002/jctb.4666

Lichtfouse E, Navarrete M, Debaeke P, et al. (2009) Sustainable agriculture. Springer Netherlands, Dordrecht

Mitchell RG, Spliethoff HM, Ribaudo LN et al (2014) Lead (Pb) and other metals in New York City community garden soils: factors influencing contaminant distributions. Environ Pollut 187:162169. doi:10.1016/j.envpol.2014.01.007

Mombo S, Foucault Y, Deola F et al (2015) Management of human health risk in the context of kitchen gardens polluted by lead and cadmium near a lead recycling company. J Soils Sediments:1-11. doi:10.1007 /s11368-015-1069-7

Montagnac JA, Davis CR, Tanumihardjo SA (2009) Nutritional value of cassava for use as a staple food and recent advances for improvement. Compr Rev Food Sci Food Saf 8:181-194. doi:10.1111 /j.1541-4337.2009.00077.x

Mombo S, Schreck E, Dumat C, Laplanche C, Pierart A, Longchamp M, Besson P, Castrec-Rouelle M (2016) Bioaccessibility of selenium after human ingestion in relation to its chemical species and compartmentalization in maize. Environ Geochem Health 38(3):869-883

Mortureux M (2012) Avis de l' Agence nationale de sécurité sanitaire de l' alimentation, de l' environnement et du travail. In: Maisons-Alfort (ed) Maisons-Alfort. 25/06/2012, France, pp 1-17

Moyo C, Benesi I, Sandifolo V, Teri J (1998) Current status of cassava and sweetpotato production and utilization in Malawi.

Nambisan B (2011) Strategies for elimination of cyanogens from cassava for reducing toxicity and improving food safety. Food Chem Toxicol 49:690-693. doi:10.1016/j.fct.2010.10.035

Nassar N, Dorea JG (1982) Protein content of cassava cultivars and its hybrid with wild Manihot species. 32:6-8.

Nassar NMA (1978) Conservation of the genetic resources of cassava (Manihot esculenta): determination of wild species localities with 
emphasis on probable origin. Econ Bot 32:311-320. doi:10.1007 /BF02864705

Ngudi DD, Kuo YH, Lambein F (2002) Food safety and amino acid balance in processed cassava "Cossettes.". J Agric Food Chem 50: 3042-3049. doi:10.1021/jf011441k

Nhassico D, Muquingue H, Cliff J et al (2008) Rising African cassava production, diseases due to high cyanide intake and control measures. J Sci Food Agric 88:2043-2049. doi:10.1002/jsfa.3337

Nkwocha EE, Pat-Mbano E, Tony-Njoku N (2011) Assessment of heavy metal concentration in food crops grown around Etelebou oil flow station in Bayelsa. Int J Sci Nat 2:665-670

Ntow WJ, Gijzen HJ, Kelderman P, Drechsel P (2006) Farmer perceptions and pesticide use practices in vegetable production in Ghana. Pest Manag Sci 62:356-365. doi:10.1002/ps.1178

Oboh G, Akindahunsi AA (2003) Biochemical changes in cassava products (flour \& gari) subjected to Saccharomyces cerevisae solid media fermentation. Food Chem 82:599-602. doi:10.1016/S03088146(03)00016-5

OECD, 2016. Chapter three of the "Safety assessment of transgenic organisms in the environment: OECD consensus documents", volume 6 ㄷ OECD 2016.

Oduwaye O a, Ojo DK, Mkumbira J et al (2014) Genetic assessment of 23 cassava, Manihot esculenta Crantz. Genotypes at Two AgroClimatic Zones in Nigeria Plant Breed Seed Sci doi. doi:10.2478 /v10129-011-0073-3

Okorie A, Entwistle J, Dean JR (2012) Estimation of daily intake of potentially toxic elements from urban street dust and the role of oral bioaccessibility testing. Chemosphere 86:460-467. doi:10.1016/j. chemosphere.2011.09.047

Oliver MA (2008) Soil and human health: a review. Eur J Soil Sci 48: 573-592. doi:10.1111/j.1365-2389.1997.tb00558.x

Olsen KM, Schaal BA (1999) Evidence on the origin of cassava: phylogeography of Manihot esculenta. Proc Natl Acad Sci U S A 96:5586-5591. doi:10.1073/pnas.96.10.5586

Onabolu a O, Oluwole OS, Bokanga M, Rosling H (2001) Ecological variation of intake of cassava food and dietary cyanide load in Nigerian communities. Public Health Nutr 4:871-876. doi:10.1079 /PHN2001127

Onyedika GO, Nwosu GU (2008) Lead, zinc and cadmium in root crops from mineralized galena-sphalerite mining areas and environment. Pakistan J Nutr 7:418-420. doi:10.3923/pjn.2008.418.420

Oshunsanya SO (2016) Alternative method of reducing soil loss due to harvesting of sweet potato: a case study of low input agriculture in Nigeria. Soil Tillage Res 158:49-56. doi:10.1016/j.still.2015.11.007

Padmavathiamma PK, Li LY (2007) Phytoremediation technology: hyper-accumulation metals in plants. Water Air Soil Pollut 184: 105-126. doi:10.1007/s11270-007-9401-5

Pandey A, Soccol CR, Nigam P et al (2000) Biotechnological potential of agro- -industrial residues: II cassava bagasse. Bioresour Technol 74: 81-87. doi:10.1016/S0960-8524(99)00143-1

Pierart A, Shahid M, Séjalon-Delmas N, Dumat C (2015) Antimony bioavailability: knowledge and research perspectives for sustainable agricultures. J Hazard Mater 289:219-234. doi:10.1016/j. jhazmat.2015.02.011

Pourrut B, Shahid M, Dumat C et al (2011) Lead uptake, toxicity, and detoxification in plants. Rev Environ Contam Toxicol 213:113-136. doi:10.1007/978-1-4419-9860-6_4

Ryser P, Sauder WR (2006) Effects of heavy-metal-contaminated soil on growth, phenology and biomass turnover of Hieracium piloselloides. Environ Pollut 140:52-61. doi:10.1016/j. envpol.2005.06.026

Sajid L, Joachim M (2014) Cassava — how to explore the "all-sufficient." In: the International Journal for Rural Development. pp 30-31
Sauer CO (1952) Agricultural origins and dispersals, American G. American Geographical Society., New York

Schmidt C (1951) A mandioca, contribuição para o conhecimento de sua origem.

Schreck E, Foucault Y, Geret F et al (2011) Influence of soil ageing on bioavailability and ecotoxicity of lead carried by process waste metallic ultrafine particles. Chemosphere 85:1555-1562. doi:10.1016 /j.chemosphere.2011.07.059

Schuhmacher M, Bocio A, Agramunt MC et al (2002) PCDD/F and metal concentrations in soil and herbage samples collected in the vicinity of a cement plant. Chemosphere 48:209-217. doi:10.1016/S00456535(02)00042-5

Scott GJ, Rosegrant MW, Ringler C (2000) Roots and tubers for the 21st century (brief). The 2020 Vision, International Food Policy Research Institute (IFPRI), 2033 K Street, N.W., Washington, DC 20006-1002, USA/ifpri-info@cgiar.org; Centro Internacional de la Papa (CIP), Apartado 1558, Lima 12, Peru

Shahid M, Dumat C, Pourrut B et al (2015a) Role of metal speciation in lead-induced oxidative stress to Vicia faba roots. Russ J Plant Physiol 62:448-454. doi:10.1134/S1021443715040159

Shahid M, Ferrand E, Schreck E, Dumat C (2013) Behavior and impact of zirconium in the soil-plant system: plant uptake and phytotoxicity. Rev Environ Contam Toxicol 221:107-127. doi:10.1007/978-14614-4448-0_2

Shahid M, Khalid S, Abbas G (2015b) Heavy metal stress and crop productivity. Crop Prod Glob Environ Issues:1-25. doi:10.1007 1978-3-319-23162-4 1

Shahid M, Pinelli E, Dumat C (2012) Review of Pb availability and toxicity to plants in relation with metal speciation; role of synthetic and natural organic ligands. J Hazard Mater 219-220

Shahid M, Pinelli E, Pourrut B et al (2011) Lead-induced genotoxicity to Vicia faba L. roots in relation with metal cell uptake and initial speciation. Ecotoxicol Environ Saf 74:78-84. doi:10.1016/j. ecoenv.2010.08.037

Sharma RK, Agrawal M, Marshall FM (2009) Heavy metals in vegetables collected from production and market sites of a tropical urban area of India. Food Chem Toxicol 47:583-591. doi:10.1016/j. fct.2008.12.016

Simate GS, Ndlovu S (2014) The removal of heavy metals in a packed bed column using immobilized cassava peel waste biomass. J Ind Eng Chem 21:635-643. doi:10.1016/j.jiec.2014.03.031

Soccol CR (1996) Biotechnology products from cassava root by solid state fermentation. J Sci Ind Res 55:358-364

Souza-Arroyo V, Martínez-Flores K, Bucio-Ortiz L et al (2012) Liver and cadmium toxicity. Drug Metab Toxicol S5:001. doi:10.4172/21577609.S5-001

Srinivas T (2007) Industrial demand for cassava starch in India. Sect Soc Sci Cent Tuber Crop Res Inst 59:477-481. doi:10.1002 /star.200700657

Tonukari NJ, Ezedom T, Enuma CC et al (2015) White gold: cassava as an industrial base. Am J Plant Sci:972-979

Tsegai D, Kormawa P (2002) Witzenhausen, 9-11 October 2002 Conference on International Agricultural Research for Development Determinants of urban households ' demand for cassava and cassava products in Kaduna, northern Nigeria : the application of AIDS model. 9-11.

Uzu G, Schreck E, Xiong T et al (2014) Urban market gardening in Africa: foliar uptake of metal(loid)s and their bioaccessibility in vegetables. Implications in Terms of Health Risks. doi:10.1007 /s11270-014-2185-5

Uzu G, Sobanska S, Aliouane Y et al (2009) Study of lead phytoavailability for atmospheric industrial micronic and sub- 
micronic particles in relation with lead speciation. Environ Pollut 157:1178-1185. doi:10.1016/j.envpol.2008.09.053

Valko M, Jomova K, Rhodes CJ, et al. (2015) Redox- and non-redoxmetal-induced formation of free radicals and their role in human disease.

Voko DRBI, Zeze A (2013) Impact Des Proprietes Physicochimiques Des Sols De Culture Du Manioc Sur L' Abondance Et La Diversite Des Communautes De Champignons Mycorhiziens À Arbuscules Dans La Zone Agroecologique D' Azaguie. Sud-Est De La Côte D' Ivoire 25:251-264

White WLB (1998) Cyanogenesis in cassava. The role of hydroxynitrile lyase in root cyanide production. Plant Physiol 116:1219-1225. doi:10.1104/pp.116.4.1219

Xiong T, Dumat C, Pierart A et al (2016) Measurement of metal bioaccessibility in vegetables to improve human exposure assessments: field study of soil-plant-atmosphere transfers in urban areas. South China Environ Geochem Health:1-19. doi:10.1007/s10653-0169796-2

Xiong T, Leveque T, Austruy A, et al. (2014a) Foliar uptake and metal(loid) bioaccessibility in vegetables exposed to particulate matter. Environ Geochem Health 897-909. doi: 10.1007/s10653-0149607-6

Xiong T, Leveque T, Shahid M et al (2014c) Lead and cadmium phytoavailability and human bioaccessibility for vegetables exposed to soil or atmospheric pollution by process ultrafine particles. J Environ Qual 43:1593-1600. doi:10.2134/jeq2013.11.0469

Xiong T-T, Leveque T, Austruy A et al (2014b) Foliar uptake and metal(loid) bioaccessibility in vegetables exposed to particulate matter. Environ Geochem Health 36:897-909. doi:10.1007/s10653-0149607-6

Yaninek JS, Schulthess F (1993) Developing an environmentally sound plant protection for cassava in Africa. Agric Ecosyst Environ 46: 305-324. doi:10.1016/0167-8809(93)90032-K

Yu S, Tao J (2009) Simulation based life cycle assessment of airborne emissions of biomass-based ethanol products from different feedstock planting areas in China. J Clean Prod 17:501-506. doi:10.1016/j.jclepro.2008.08.022

Zhang C, Han W, Jing X et al (2003) Life cycle economic analysis of fuel ethanol derived from cassava in southwest China. Renew Sust Energ Rev 7:353-366. doi:10.1016/S1364-0321(03)00057-1

Zhu W, Lestander TA, Orberg H et al (2015) Cassava stems: a new resource to increase food and fuel production. GCB Bioenergy 7: 72-83. doi:10.1111/gcbb.12112

Ziska LH, Runion GB, Tomecek M et al (2009) An evaluation of cassava, sweet potato and field corn as potential carbohydrate sources for bioethanol production in Alabama and Maryland. Biomass Bioenergy 33:1503-1508. doi:10.1016/j.biombioe.2009.07.014 